\title{
Quantitative deposition of nutrients in dorsal muscle, adipose tissue and liver in common carp (Cyprinus carpio L.) in a semi-intensive farming system
}

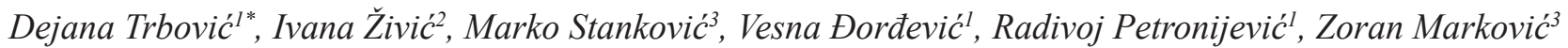

A b s tr a c t: Carp is the dominant species grown in Serbia and makes up over $80 \%$ of the total fish production. The aims of the present study were to analyze changes of protein, lipid, ash and moisture in dorsal muscle, adipose tissue and liver in common carp additionally fed complete pellets during four months in natural carp ponds. Twenty fish from four ponds were sampled. Analysis of variance showed that protein content was the highest in dorsal muscle and adipose tissue and was the smallest in liver $(P<0.05)$. The percentage of protein was quite stable and reached a plateau value (18.42-19.49\%) in dorsal muscle. Total lipid content in common carp was the highest in liver (14.79-17.24\%) and smaller in dorsal muscle (1.92-5.42\%) $(P<0.05)$. More interested were how the fish mass increased during breeding. The proximate composition of fish tissues was expressed as absolute content by weight of each fish. Simple regression resulted in relationships between protein content $(g / f i s h)$ and body weight $(g)$ indicating strong association $(r=0.965)$. Simple regression resulted in not strong relationships between lipid content $(\mathrm{g} /$ fish $)$ and body weight $(g(r=0.784)$. There was a strong relationship between moisture content $(\%)$ and lipid content $(\%)(r=0.962)$. The protein content $(g / f i s h)$ was strongly associated with body weight in dorsal muscle and adipose tissue since coefficients of regression were high (>0.95), as were t-tests of significance (13.69, 18.04), and in the liver there was also an association since the coefficient of regression was 0.952 and the t-test was high (11.72).

Keywords: proximate composition, protein, fish weight, growth curve.

\section{Introduction}

Cyprinids are by far the largest family of farmed finfish (20.4 million t or $71.1 \%$ ). These are mostly produced by Asian family enterprises and consumed locally (FAO, 2020). Cyprinids are the most important cultivated species of fish in central-eastern Europe, contributing $75 \%$ of the production of freshwater fish (Váradi et al., 2011). Carp is the dominant species grown in Serbia and makes up over $80 \%$ of the total fish production. Carp production is mostly in semi-intensive production systems based on a combination of natural and supplementary feed, cereals or complete extruded or pelleted feed. Recently, more than $50 \%$ of the carp were additionally fed by complete, primarily extruded feed (Markovic \& Poleksić, 2011), which enabled more intensive carp production and the development of aquaculture in Serbia. With an increase in the fish weight come increases in the levels of body components such as moisture, protein, phospholipids, triglycerides, nucleic acids etc. (Bureau et al., 2000;
Dumas et al., 2010) since fish use these as building blocks and energy sources for maintenance of life processes. Specific growth rate is a widely accepted model in aquaculture in spite of its disadvantages, and is based on determining the natural logarithm of the increase in the total weight of fish over a certain period of time. The main disadvantage of this model is that the growth rate varies with the size of the fish and also with the ambient temperature, which often leads to underestimation of weight gain (Bureau et al., 2000; Dumas et al., 2010). Daily growth coefficient (DGC), which is the cube root of the weight increase of fish within a certain time, better describes fish growth under optimal conditions. The best way to discover the relationship between the processes that were taking place in the body of the fish depending on the change in mass is a graphic representation of a variable size versus body mass using the equation $\mathrm{Y}=\mathrm{aX}$, where $\mathrm{Y}$ is the variable that needs to be determined, $\mathrm{X}$ is body weight, $a$ and $b$ are empirical constants derived from regression.

${ }^{1}$ Institute of Meat Hygiene and Technology, Kaćanskog 13, 11000 Belgrade, Republic of Serbia;

${ }^{2}$ University of Belgrade, Faculty of Biology, Studentski trg 16, 11000 Belgrade, Republic of Serbia;

${ }^{3}$ University of Belgrade, Faculty of Agriculture, Nemanjina 6, 11080 Belgrade, Republic of Serbia.

*Corresponding author: Dejana Trbović, dejana.trbovic@inmes.rs 
Exponent $b$ is of particular importance because it provides a scaling relationship between the size such as metabolism and body weight. This mathematical technique is called allometric analysis (Gayon, 2000) and is widely used to describe the rate at which changes are taking place in various tissues of animals as well as in fish (Shearer, 1994; Azevedo et al., 1998; Lupatsch et al., 1998; Bureau et al., 2000; Dumas et al., 2007). Common carp has been studied in basic as well as applied research (Vandeputte et al., 2008; Turkowski \& Lirski, 2010).

The aims of the present study were to analyze changes of protein, lipid, ash and moisture in dorsal muscle, adipose tissue and liver in common carp additionally fed complete pellets during four months in natural carp ponds rather than fully controlled fish tanks to make results directly applicable to real world aquaculture.

Since in the literature there is not enough data to explain how diet composition influences the retention of protein, lipid and ash in several tissues of farm-raised two year old common carp, this study was designed assuming that dietary supply is tissue specific to make results applicable to aquaculture.

\section{Materials and methods}

\section{Samples}

The study was carried out in four earthen ponds at the Despotovo fish farm (near the city of Backa Palanka, Vojvodina province, decimal degree 45.44 19.54) from July to October. Four fish ponds (J1, J3, J4 and J6) were used with surface area of 100 ha, 25 ha, 25 ha and 16 ha, respectively. The depth was the same in ponds, around $1.5 \mathrm{~m}$. All ponds were stocked with 550 specimens of two-year-old common carp ha ${ }^{-1}$ in June, with an average weight of $750 \mathrm{~g}$. Fish were fed with standard supplemental pelleted feed containing a mixture of soybean, maize, wheat with $25 \%$ protein (plant origin) and $7 \%$ lipid, at a feeding rate of $2.5 \%$ of total fish body mass. Fish were collected monthly from ponds. Twenty fish from four ponds were sampled; each fish was weighed and measured, then the dorsal muscle, adipose muscle and liver were separated and frozen immediately. Samples were kept at $-20^{\circ} \mathrm{C}$ until analysis.

\section{Proximate chemical analysis of fish}

Analysis of moisture (ISO 1442:1997), lipid (ISO 1443:1973) and ash (ISO 936:1998) were performed according to standard ISO methods.
Protein (Kjeldahl nitrogen) was analyzed by using a semi-automatic distillation unit (Kjeltec Auto 1030 Analyzer), with block-digestion apparatus (Digestion System 20, Tecator, Höganäs, Sweden) according to the manufacturer's instructions (Tecator Manual Rev. 2.2).

\section{Statistical analysis}

The obtained data are reported as the mean values \pm the standard deviations. Analysis of variance (ANOVA) and the Tukey-Kramer test were used to analyze the data at the level of significance of 0.05 ( $\mathrm{P} \leq 0.05)$. For statistical analysis and regression analysis, XLSTAT Free version (Addinsoft, NY, USA) was used. All the allometric equations were obtained by applying linear regression analysis to the logarithmic transformation. The antilog of this expression produces the final equation: $\mathrm{y}=\mathrm{aX}$.

\section{Results and discussion}

Proximate composition (protein, moisture, total lipids and ash) in dorsal muscle, adipose tissue and liver determined in July, August, September and October are given in Table 1.

Analysis of variance showed that protein content was the highest in dorsal muscle and adipose tissue and was the smallest in liver $(\mathrm{P}<0.05)$. The percentage of protein was quite stable and reached a plateau value (18.42-19.49\%) in dorsal muscle. This profile has also been reported for other cyprinid and salmonid species (Shearer, 1994; Fauconneau et al., 1995). In reared Diplodus puntazzo fillets, the protein percentage was around 18\% (Orban et al., 2000). Very minor protein content changes are observed when fish are fasted (Shimeno et al., 1990) or fed an imbalanced diet (Venugopal \& Keshavanath, 1984), whereas sexual maturation has been reported to strongly affect this component (Dhawan \& Toor, 1990). Total lipids in common carp were the highest in liver and were smaller in dorsal muscle $(\mathrm{P}<0.05)$. Total lipids were lower than in the study of Urbánek et al. (2010). The moisture content follows a similar picture as lipid content (Turchini et al., 2004; Lupatsch et al., 2008). In the current study, the moisture content was slightly lower in liver than in dorsal muscle and adipose tissue $(\mathrm{P}<0.05)$. With respect to the two remaining components, water and lipids, water is easiest to determine, so the lipid content can be calculated by subtraction (Hernández et al. 2003). The 
Table 1. Proximate composition (\% of wet weight) of dorsal muscle, adipose tissue and liver of carp from the four carp fish farms $(\mathrm{n}=20)$ from July to October

\begin{tabular}{llcccc}
\hline \multicolumn{1}{c}{ Parameter } & Muscle /period & July & August & September & October \\
\hline Protein & Dorsal muscle & $19.49 \pm 0.30^{\mathrm{a}}$ & $20.22 \pm 1.11^{\mathrm{a}}$ & $19.74 \pm 1.21^{\mathrm{a}}$ & $18.42 \pm 0.66^{\mathrm{a}}$ \\
& Adipose tissue & $18.61 \pm 0.48^{\mathrm{a}}$ & $19.25 \pm 0.63^{\mathrm{a}}$ & $18.88 \pm 0.19^{\mathrm{a}}$ & $18.11 \pm 0.33^{\mathrm{a}}$ \\
& Liver & $12.45 \pm 0.77^{\mathrm{b}}$ & $13.85 \pm 1.04^{\mathrm{b}}$ & $13.72 \pm 0.43^{\mathrm{b}}$ & $12.44 \pm 0.37^{\mathrm{b}}$ \\
\hline Moisture & Dorsal muscle & $77.42 \pm 0.61^{\mathrm{a}}$ & $77.65 \pm 1.54^{\mathrm{a}}$ & $76.12 \pm 0.23^{\mathrm{a}}$ & $73.41 \pm 1.66^{\mathrm{a}}$ \\
& Adipose tissue & $75.77 \pm 0.37^{\mathrm{a}}$ & $76.04 \pm 1.67^{\mathrm{a}}$ & $73.48 \pm 1.27^{\mathrm{a}}$ & $72.62 \pm 0.68^{\mathrm{a}}$ \\
& Liver & $68.29 \pm 2.30^{\mathrm{b}}$ & $68.98 \pm 2.13^{\mathrm{b}}$ & $68.01 \pm 3.08^{\mathrm{b}}$ & $67.77 \pm 3.53^{\mathrm{a}}$ \\
\hline \multirow{2}{*}{ Total lipids } & Dorsal muscle & $1.92 \pm 0.56^{\mathrm{b}}$ & $2.84 \pm 0.87^{\mathrm{b}}$ & $2.93 \pm 0.96^{\mathrm{b}}$ & $5.42 \pm 1.10^{\mathrm{b}}$ \\
& Adipose tissue & $3.63 \pm 0.27^{\mathrm{b}}$ & $3.20 \pm 0.68^{\mathrm{b}}$ & $5.27 \pm 1.65^{\mathrm{b}}$ & $6.85 \pm 1.17^{\mathrm{ab}}$ \\
& Liver & $17.34 \pm 3.25^{\mathrm{a}}$ & $16.57 \pm 3.51^{\mathrm{a}}$ & $15.52 \pm 4.02^{\mathrm{a}}$ & $14.79 \pm 5.38^{\mathrm{a}}$ \\
\hline \multirow{2}{*}{ Ash } & Dorsal muscle & $1.25 \pm 0.13^{\mathrm{ab}}$ & $1.15 \pm 0.08^{\mathrm{a}}$ & $1.19 \pm 0.24^{\mathrm{a}}$ & $1.33 \pm 0.10^{\mathrm{a}}$ \\
& Adipose tissue & $1.46 \pm 0.17^{\mathrm{a}}$ & $1.50 \pm 0.56^{\mathrm{a}}$ & $1.38 \pm 0.32^{\mathrm{a}}$ & $1.25 \pm 0.22^{\mathrm{a}}$ \\
& Liver & $1.09 \pm 0.19^{\mathrm{b}}$ & $1.11 \pm 0.04^{\mathrm{a}}$ & $0.98 \pm 0.13^{\mathrm{a}}$ & $1.06 \pm 0.06^{\mathrm{a}}$ \\
\hline
\end{tabular}

Legend: $n$ - number of samples; $a, b, c$ Means within the same column sharing the same letter are not significantly different $(p>0.05)$

ash content did not statistically significantly differ between tissues $(\mathrm{P}>0.05)$.

More revealing was how the fish mass increased during breeding. The proximate composition of fish tissues was expressed as absolute content by weight for each fish. Plots of carp body weight by sampling day of are presented in Figure 1.

Simple regression resulted in relationships between protein content ( $\mathrm{g} /$ fish) and body weight $(\mathrm{g}$ )

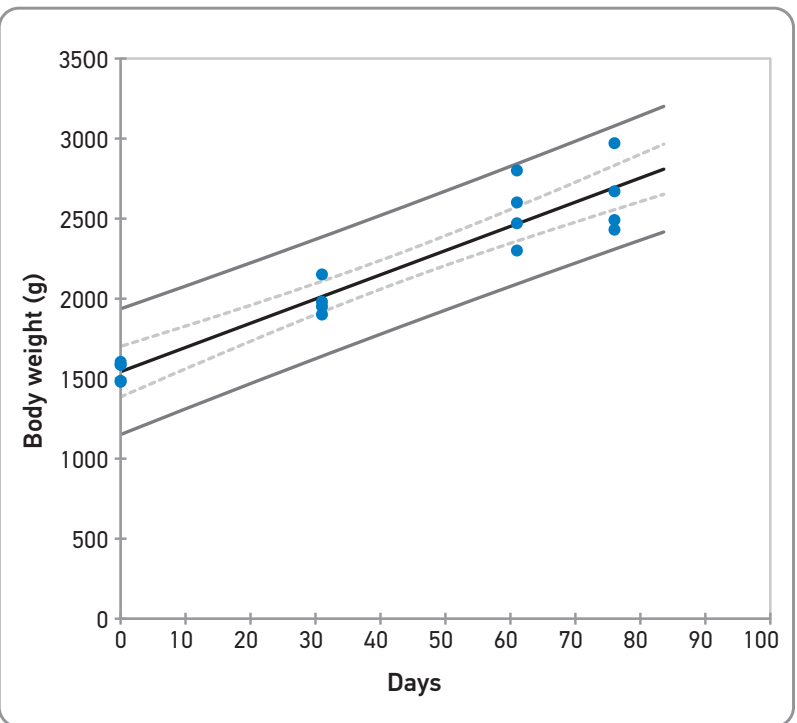

Figure 1. Growth curve of carps in four farms during rearing $(r=0.942)$ from July to October) indicating strong association (Figure 2) according to Dumas et al. (2007) and Bureau et al. (2000).

Simple regression resulted in not strong relationships between lipid content $(\mathrm{g} /$ fish) and body weight (g) (Figure 3) according to Dumas et al. (2007) and Bureau et al. (2000). Lipids were more affected by feeding regime (Dumas et al., 2007; Bureau et al., 2000; Turchini et al., 2004; Cook et al., 2000; Hernández et al., 2003).

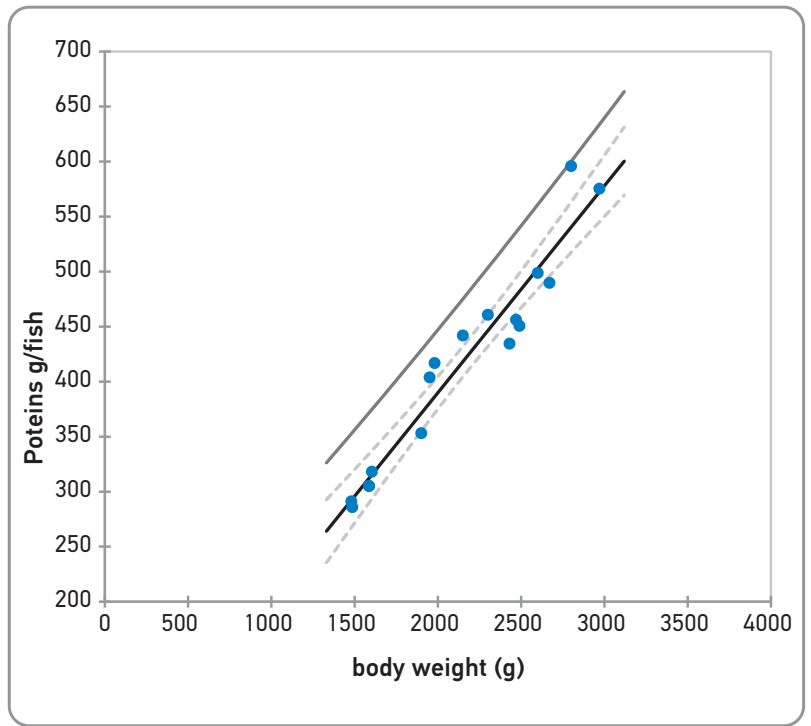

Figure 2. Quantitative deposition of protein in dorsal muscle $(\mathrm{r}=0.965)$ 


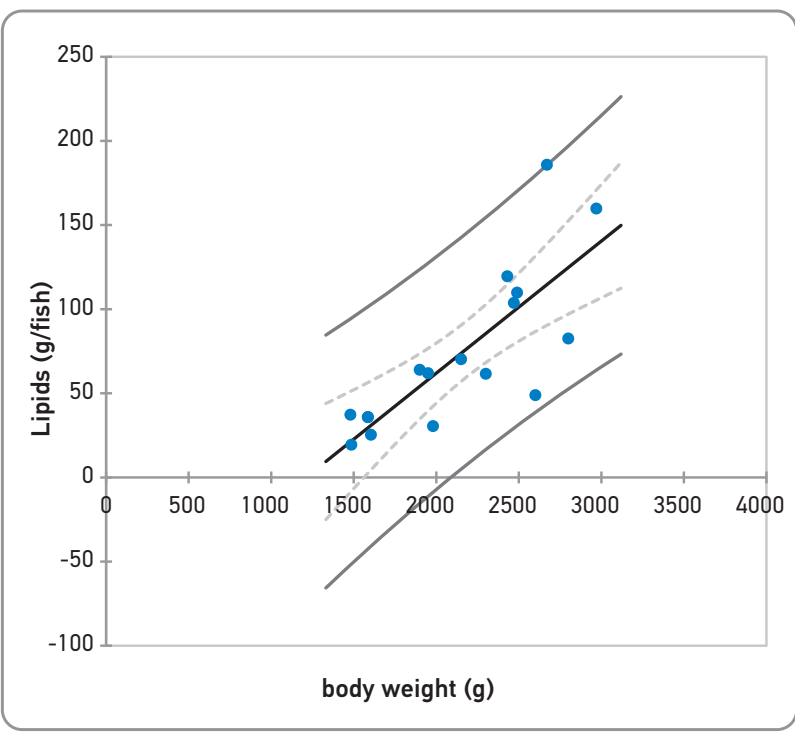

Figure 3. Quantitative deposition of lipids in dorsal tissue $(r=0.784)$

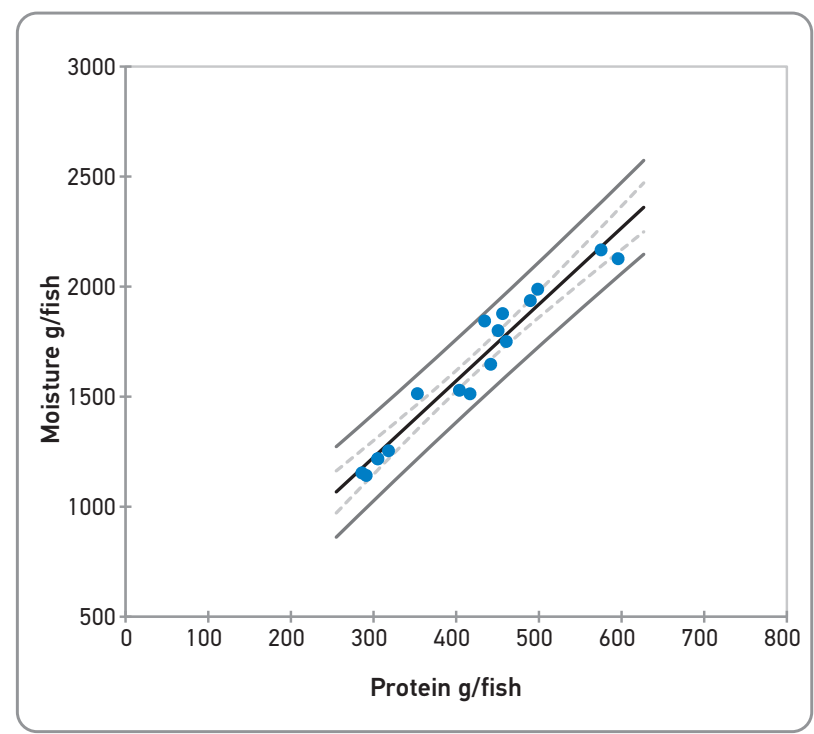

Figure 4. Relationship between moisture (g/fish) and protein (g/fish) in the whole-body of common carp of dorsal muscle $(r=0.902)$

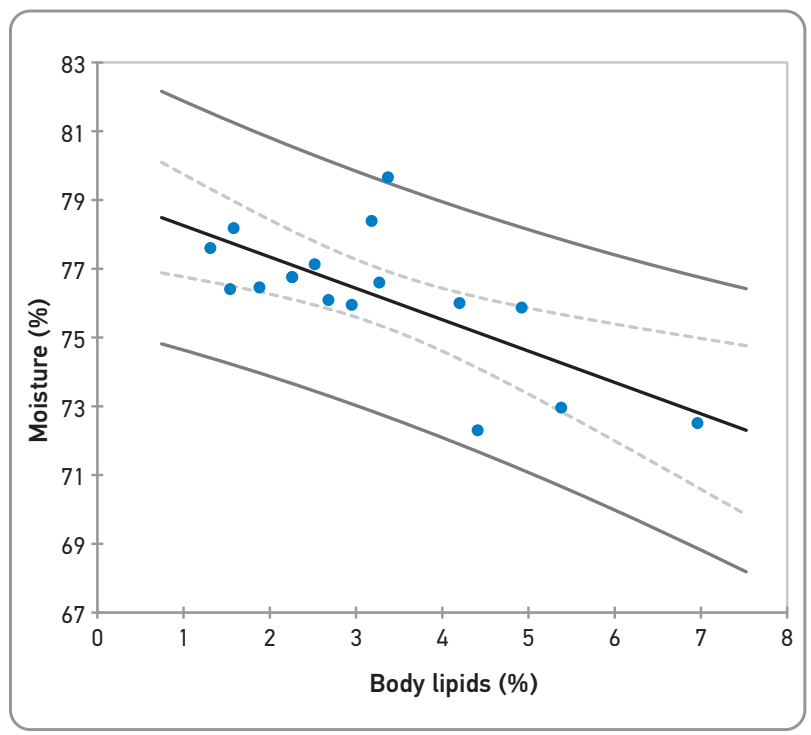

Figure 5. Relationship between relative content of lipid (\%) and moisture (\%) in the whole-body of common carp of dorsal muscle $(r=0.692)$

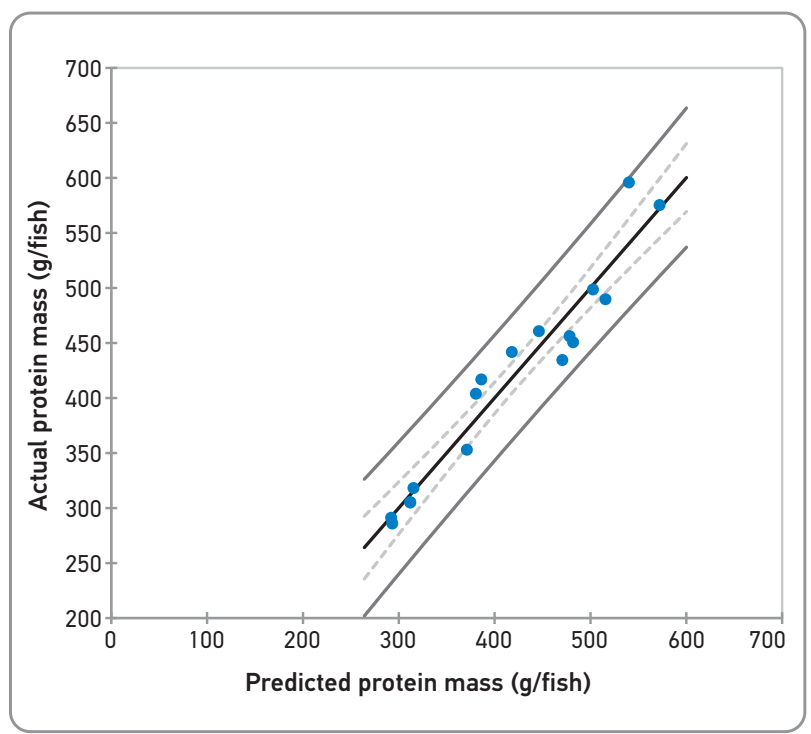

Figure 6. Experimentally obtained values of protein mass gain depending on the theoretical value of protein mass gain in the dorsal carp muscle $(\mathrm{r}=$ 0.965) (from July to October)

Table 2. Coefficients of regression of protein content (g/fish), Y, of carp weight, $\mathrm{X}(\mathrm{g})$ :

\begin{tabular}{cllccccc}
\hline $\mathbf{Y}$ (g/fish) & & $\mathbf{a}$ & $\mathbf{b}$ & $\mathbf{r}$ & $t$ & $\mathbf{p}$ \\
\hline \multirow{2}{*}{ Protein content } & Dorsal muscle & 0.188 & 13.81 & 0.964 & 13.69 & $* * *$ \\
& Adipose tissue & 0.174 & 24.03 & 0.980 & 18.64 & $* * *$ \\
& Liver & 0.129 & 4.02 & 0.952 & 11.72 & $* * *$ \\
\hline
\end{tabular}

Legend: $a$ and $b-$ empirical constants; $r-$ coefficient of regression; $t-t$ test, $p$ - level of significance $* * *$ significantly different $(p>0.001)$ 
There was a strong relationship between moisture content ( $\mathrm{g} / \mathrm{fish})$ and protein content $(\mathrm{g} / \mathrm{fish})$ (Figure 4) according to Dumas et al. 2007, Bureau et al. (2000) and Breck (2014).

There was a strong relationship between moisture content (\%) and lipid content (\%) (Figure 5) according to Dumas et al. (2007), Bureau et al. (2000), Breck (2014) and Mohseni et al., (2007).

The effect of body size on protein content $(\mathrm{g} /$ fish) in dorsal muscle, adipose tissue and liver is given in Table 2.

From Table 2 it can be seen that protein content (g/fish) was strongly associated with body weight in dorsal muscle and adipose tissue since coefficients of regression were high $(>0.95)$ as was $t$-test of significance, but in the liver there was a slightly weaker association, since the coefficient of regression was 0.952 , while the $t$-test was high. This is in accordance with Turchini et al. (2004) for a slightly different study. Figure 6 shows graphically the protein prediction in fish, depending on the actual prediction. The data in Figure 6 were obtained by calculating the protein content ( $\mathrm{g} /$ fish) representing predicted protein for the same mass of fish from the equation.

\section{Conclusion}

Cyprinids are the most important cultivated species of fish in central-eastern Europe with a 75\% contribution to the production of freshwater fish. The aims of the present study were to analyze changes of protein, lipid, ash and moisture in dorsal muscle, adipose tissue and liver in common carp additionally fed complete pellets during four months in natural carp ponds rather than in fully controlled fish tanks, and to make the results directly applicable to real world aquaculture. Since in the literature there is not enough data to explain how diet composition influences the retention of protein, lipid and ash in several tissues of farm-raised two year old common carp, this study was designed assuming that the dietary supply is tissue specific to make results applicable to aquaculture. The proximate composition of fish tissues was expressed as absolute content by weight of each fish. Simple regression resulted in relationships between protein content (g/fish) and body weight $(\mathrm{g})$, indicating a strong association. There is a strong relationship between moisture content (\%) and lipid content. Simple regression resulted in not strong relationships between lipid content $(\mathrm{g} /$ fish) and body weight $(\mathrm{g})$. There is a strong relationship between moisture content ( $\mathrm{g} /$ fish) and protein content ( $\mathrm{g} /$ fish).

\title{
Kvantitativno taloženje hranljivih sastojaka u dorzalnom mišiću, masnom tkivu i jetri kod šarana (Cyprinus carpio L.) u poluintenzivnom sistemu uzgoja
}

\author{
Dejana Trbović, Ivana Živić, Marko Stanković, Vesna Đorđević, Radivoj Petronijević, Zoran Marković
}

A p s tr a k t: Šaran je dominantna vrsta koja se uzgaja u Srbiji i čini preko $80 \%$ ukupne proizvodnje ribe. Ciljevi ove studije bili su analiza promena proteina, masti, pepela i vlage u dorzalnom mišiću, masnom tkivu i jetri kod šarana dodatno hranjenih kompletnim peletima tokom četiri meseca u prirodnim ribnjacima. Uzorkovano je 20 riba iz četiri ribnjaka. Analiza varijanse pokazala je da je udio proteina najveći u mišićima dorzalnog tkiva i masnom tkivu, a najmanji u jetri $(P<0,05)$. Procenat proteina je prilično stabilan $i$ dostiže vrednost $(18,42-19,49 \%)$ u dorzalnom mišiću. Ukupni sadržaj lipida u šaranu bio je najveći u jetri $(14,79-17,24 \%)$ i manji $u$ dorzalnim mišićima $(1,92-5,42 \%)(P<0,05)$. Više je interesantno kako se riblja masa povećavala tokom uzgoja. Prosečan sastav ribljih tkiva izražen je kao apsolutni sadržaj mase svake ribe. Jednostavna regresija pružila je odnos između sadržaja proteina (g/riba) $i$ telesne mase $(g)$ što ukazuje na jaku povezanost $(r=0,965)$. Jednostavna regresija pruža slabu vezu između sadržaja lipida ( $g / r i b a)$ $i$ telesne mase $(r=0,784)$. Postoji snažna veza između sadržaja vlage (\%) i sadržaja lipida (\%) $(r=0,962)$. Prema našem saznanju može se videti da je sadržaj proteina (g/riba) snažno povezan sa telesnom masom u dorzalnom mišiću i masnom tkivu s obzirom da je koeficijent regresije visok (>0,95), kao i t test značajnosti $(13,69,18,04)$, ali i u jetri je postojala povezanost, jer je koeficijent regresije bio 0,952, a t test visok $(11,72)$.

Ključne reči: prosečan sastav, proteini, masa ribe, kriva rasta

Disclosure statement: No potential conflict of interest was reported by authors.

Acknowledgements: This study was supported by the Ministry of Education, Science and Technological Development of the Republic of Serbia, according to the provisions of the Contract on research financing in 2021 (No 451-03-9/2021-14/200050 dated 05. 02. 2021). 


\section{References}

Azevedo, P. A., Cho, C. Y., Leeson, S. \& Bureau, P. D. (1998). Effects of feeding level and water temperature on growth, nutrient and energy utilization and waste outputs of rainbow trout (Oncorhynchus mykiss). Aquatic Living Resources, 11, 227-238.

Breck J. E. (2014). Body composition in fishes: body size matters. Aquaculture, 433, 40-49. https://doi.org/10.1016/j. aquaculture.2014.05.049

Bureau, D. P., Azevedo, P. A., Tapia-Salazar, M. \& Cuzon, G. (2000). Pattern and cost of growth and nutrient deposition in fish and shrimp: Potential implications and applications, In: Cruz-Suárez, L.E., Ricque-Marie, D., Tapia-Salazar, M., Olvera-Novoa, M.A. Civera-Cerecedo, R. (Eds.), Avances en Nutrición Acuícola V. Memorias del V Simposium Internacional de Nutrición Acuícola. 19-22 Noviembre, 2000. Mérida, Yucatán, Mexico, 111-140.

Cook J. T., McNiven M. A., Richardson G. F. \& Sutterlin A. M. (2000). Growth rate, body composition and feed digestibilityrconversion of growth-enhanced transgenic Atlantic salmon (Salmo salar). Aquaculture, 188, 15-32. DOI: $10.1016 / \mathrm{s} 0044-8486(00) 00331-8$

Dhawan, A. \& Toor, H. S. (1990). Changes in the biochemical components of flesh of an Indian major carp (Cirrhinas mrigala Hamilton) in relation to feeding and sexual maturation. Indian Journal of Animal Science, 60, 122- 126. https://doi.org/10.1016/S0044-8486(00)00331-8

Dumas, A., Lange de F. M. C., France, J. \& Bureau, P. D. (2007). Quantitative description of body composition and rates of nutrient deposition in rainbow trout (Oncorhynchus mykiss), Aquaculture, 273, 165-181. DOI:10.1016/j. aquaculture.2007.09.026

Dumas, A., France, J. \& Bureau, D. (2010). Modelling growth and body composition in fish nutrition: where have we been and where are we going? Aquaculture Research, 41, 161-181.https://doi.org/10.1111/j.1365-2109.2009.02323.x

FAO (2020). The State of World Fisheries and Aquaculture sustainability in action. FAO Fisheries and Aquaculture Department, FAO, Rome, Italy, 206. www.fao.org

Fauconneau, B., Alami-Durante, H., Laroche, M., Marcel, J. \& Vallot, D. (1995). Growth and meat quality relations in carp. Aquaculture, 129, 265-297. https://doi. org/10.1016/0044-8486(94)00309-C

Gayon, J.(2000). History of the concept of allometry. American Zooligist, 40, 748-758. http://dx.doi.org/10.1668/0003-1569

Hernández, M. D, Egea M. A. Rueda F. M., Martıínez, F. J. \& García García, B. (2003). Seasonal condition and body composition changes in sharpsnout seabream $(D i-$ plodus puntazzo) raised in captivity. Aquaculture, 220, 569-580. https://doi.org/10.1016/S0044-8486(02)00638-5

ISO 1442:1997. Meat and meat products — Determination of moisture content (Reference method). International Organization for Standardization, Geneva, Switzerland.

ISO 1443:1973. Meat and meat products - Determination of total fat content. International Organization for Standardization, Geneva, Switzerland.
ISO 936:1998. Meat and meat products - Determination of total ash. International Organization for Standardization, Geneva, Switzerland.

Lupatsch, I., Kissil, G.Wm., Sklan, D. \& Pfeffer, E. (1998). Energy and protein requirement for maintenance and growth in gilthead seabream (Sparus aurata L.). Aquaculture Nutrition 4, 165-173. https://doi.org/10.1046/ j.1365-2095.1998.00065.x

Marković, Z. \& Poleksić, V. (2011). Akvakultura i ribarstvo u Srbiji - Aquaculture and fishery in Serbia, prof. dr. Zoran Marković, 289.

Mohseni, M., Sajjadi M. \& Pourkazemi M. (2007). Growth performance and body composition of sub-yearling Persian sturgeon (Acipenser persicus, Borodin, 1897), fed different dietary protein and lipid levels. Journal of Applied Ichthyology, 23, 204-208. https://doi.org/10.1111/ j.1439-0426.2007.00866.x

Orban, E., Di Lena, G., Ricelli, A., Paoletti, F., Casini, I., Gambelli, L. \& Caproni, R. (2000). Quality characteristics of sharpsnout sea bream (Diplodus puntazzo) from different intensive rearing systems. Food Chemistry, 70, 27-32. https://doi.org/10.1016/S0956-7135(99)00112-7

Shearer, K. D. (1994). Factors affecting the proximate composition of cultured fishes with emphasis on salmonids. Aquaculture, 119, 63-88. https://doi.org/10.1016/0044-8486(94)90444-8

Shimeno, S., Kheyvyali, D. \& Takeda, M. (1990). Metabolic adaptation to prolonged starvation in carp. Nippon Suisan Gakkaishi, 56, 35-41. https://doi.org/10.1016/S0044$\underline{8486(96) 01492-5}$

Turchini, M. G., Mentasti, T., Crocco, C., Sala, T., Puzzi, C., Moretti, M. V. \& Valfrè, F. (2004). Effects of the extensive culture system as finishing production strategy on biometric and chemical parameters in rainbow trout. $A q$ uaculture Research, 35, 378-384. https://doi.org/10.1111/ j.1365-2109.2004.01026.x

Turkowski, K. \& Lirski, A. (2010). The economics of carp farms in Poland. Acta Ichthyologica Et Piscatoria, 40, 137-144. DOI: $10.3750 / A I P 2010.40 .2 .06$

Urbánek M., Hartvich, P., Vácha F. \& Rost M. (2010). Investigation of fat content in market common carp (Cyprinus carpio) flesh during the growing season. Aquaculture Nutrition, 16, 511-515. https://doi.org/10.1111/j.1365-2095.2009.00690.x

Vandeputte, M., Kocourc M., Maugera, S., Rodina, M., Launay, A., David, G., Dupont-Nivet, M. Hulak, M. \& Linhart, O. (2008). Genetic variation for growth at one and two summers of age in the common carp (Cyprinus carpio L.): Heritability estimates and response to selection. $A q$ uaculture, 277, 7-13.

Váradi, L., Lane, A., Harache, Y., Gyalog, G., Békefi, E. \& Lengyel P. (2011). Regional Review on Status and Trends in Aquaculture Development in Europe - 2010. FAO Fisheries and Aquaculture Circular 1061/1, FAO, Rome, Italy, 257. www.fao.org

Venugopal, M. N. \& Keshavanath, P. (1984). Formulation, stability and keeping quality of three pelleted feeds used in carp culture. Fishery Technology, 21, 11-15. http://aquaticcommons.org/id/eprint/18425 